\title{
Impacts of Solar Power on Operating Reserve Requirements
}

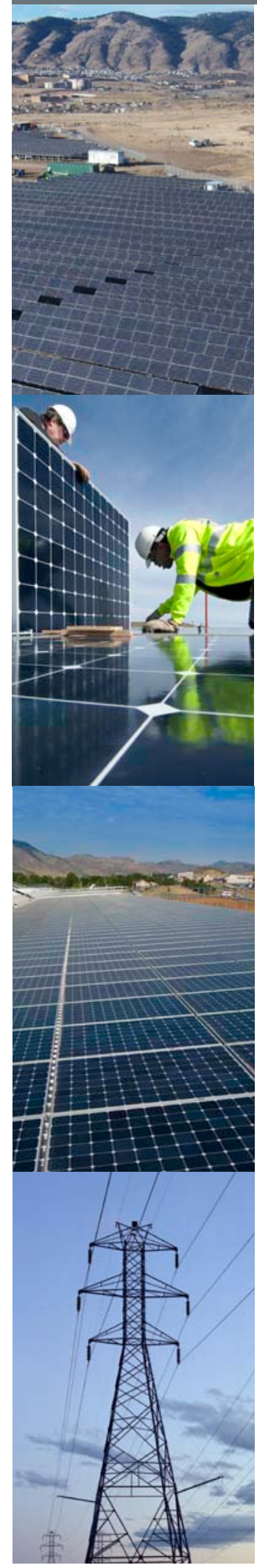

Reserves Help Operators Integrate High

Penetrations of Solar Power

Electric power system operators use a variety of scheduling techniques to match electricity generation and demand. When the total supply of energy is different from the total demand, operating reserves are deployed to correct the energy imbalance.

Imbalances on an electric power system can occur for many reasons, including the sudden loss of a large generating unit (a rare event), changes in electricity demand, and changes in the output of solar generation because of cloud cover (a normal characteristic of variable renewable generation). The contribution of operating reserves therefore varies by direction (increase or decrease in power), speed of response, and duration of response as well as by how the response is dictated (locally, centrally and automatic, or centrally and manual).

The operating reserves required will depend on the characteristics of the power system and reliability criteria. Although many electric power system operators and researchers agree that increased penetrations of solar power on the electric power system will likely increase the need for operating reserves, the amounts and types of operating reserves needed are difficult to assess.

\section{Regulating Reserves}

Regulating reserves (also called regulation, automatic generation control, and load frequency control) are capacity above or below scheduled generation used to correct the continuous, fast, frequent changes in load and generation and any differences from forecasted conditions. They correct variations within the shortest applicable market interval (between five minutes and one hour).

Regulating reserves usually respond through automatic generation control. The objective is to reduce the area control error, which is a proxy for the actual imbalance of a particular balancing authority area. ${ }^{*}$ It is calculated by summing the interchange scheduling error of the balancing authority with that of its neighbors and the energy error that is the cause of the electrical frequency deviation.
Regulating reserve requirements are usually based on compliance criteria such as the North American Electric Reliability Corp. control performance standards 1 and 2. Because photovoltaic solar can vary within a market interval and solar forecasts do not have perfect accuracy, as more solar power is added to an electric power system, regulating reserve requirements will likely be affected.

\section{Following Reserves}

Following reserves (also called load-following or balancing reserves) are capacity above or below scheduled generation used to correct anticipated imbalances on the system. Following reserves are similar to regulating reserves, but they have a slower response because they correct anticipated changes rather than current imbalances.

Following reserves often do not need automatic generation control. They may be directed by system operators and controlled manually. In today's electric power systems, balancing authorities do not often carry following reserves explicitly because loads are fairly predictable and reliability criteria do not dictate the need. However, because longer-term solar forecasts do not have perfect accuracy, as more solar power is added to an electric power system, it is possible that the need for following reserves may increase.

\section{Contingency Reserves}

Contingency reserves (also called spinning and nonspinning reserves) are capacity available for assistance during rare, sudden events that require more severe balancing than that needed during normal conditions. These events are typically caused by the sudden loss of a large generating unit or the loss of a large block of load. In these instances, the electrical frequency of the system deviates from its scheduled level. The reserves must stabilize the frequency, return it to its scheduled level, and ensure the system is brought back to a secure state. Contingency reserves are often further categorized into primary, secondary, and tertiary reserves.

Generally, variations caused by variable renewable generation such as solar energy are not instantaneous; thus, increased solar penetrations on a power system will likely not impact required contingency reserves. 


\section{Operating Reserves}

\begin{tabular}{|c|c|c|c|c|c|c|}
\hline \multicolumn{3}{|c|}{ Nonevent } & \multicolumn{3}{|c|}{ Event } & \\
\hline Regulating Reserves & Following Reserves & & $\begin{array}{l}\text { Contingency } \\
\text { Reserves }\end{array}$ & & Ramping & erves \\
\hline Automatic & Manual & & Instantaneous & & Non-Insta & neous \\
\hline $\begin{array}{l}\text { (Within Optimal } \\
\text { Dispatch) }\end{array}$ & $\begin{array}{l}\text { (Part of Optimal } \\
\text { Dispatch) }\end{array}$ & Primary & Secondary & Tertiary & Secondary & Tertiary \\
\hline $\begin{array}{l}\text { Correct the current } \\
\text { area control error }\end{array}$ & $\begin{array}{c}\text { Correct the } \\
\text { anticipated area } \\
\text { control error }\end{array}$ & $\begin{array}{l}\text { Stabilize } \\
\text { frequency }\end{array}$ & $\begin{array}{l}\text { Return frequency } \\
\text { to nominal and/ } \\
\text { or area control } \\
\text { error to zero }\end{array}$ & $\begin{array}{l}\text { Replace primary } \\
\text { and secondary }\end{array}$ & $\begin{array}{c}\text { Return } \\
\text { frequency to } \\
\text { nominal and/ } \\
\text { or area control } \\
\text { error to zero }\end{array}$ & $\begin{array}{c}\text { Replace } \\
\text { secondary }\end{array}$ \\
\hline
\end{tabular}

Figure 1. When a disturbance occurs, the electrical frequency of the system deviates from its scheduled level. The reserve must stabilize the frequency, return it to its scheduled level, and ensure the system is brought back to a secure state.

\section{Ramping Reserves}

Ramping reserves are a new category typically not procured in today's systems. Ramping reserves are capacity available for assistance during unexpected, infrequent, and severe events that are not instantaneous in nature. Examples are large, unanticipated changes in the output of wind or solar power that cannot be forecasted and occur over an hour or more. Because these events are not instantaneous, they are different from those served by contingency reserves. And because they are rare and severe, they are different from those events served by following reserves. The National Renewable Energy Laboratory (NREL) is currently researching the impact that solar power has on the need for ramping reserves.

\section{Analysis}

Myriad terms can be used to describe operating reserve needs, and they can be categorized in many ways. NREL's categorization is intended only to provide a common framework. It does not necessarily mean that separate requirements must be made for each operating reserve type or that capacity cannot be shared for different reasons.

Methods for calculating operating reserve requirements in today's power systems vary significantly among regions and even more so among studies that evaluate the impacts of variable renewable generation. Preliminary results from such studies at NREL suggest:

- Operating reserve requirements should be dynamic, not static, and change based on system conditions.

- Operating reserve requirements depend on the operating strategy (such as dispatch interval frequency).

- Often, operating reserve requirements can be reduced when sharing occurs between regions.
- More accurate wind and solar forecasts will likely reduce operating reserve requirements significantly.

- It is not difficult to have enough operating reserves; it is difficult to have enough operating reserves at a low cost and acceptable risk.

- New technologies - including energy storage, demand response, and variable renewable generation itself-can provide components of needed operating reserves.

\section{Associated Publications}

E. Ela, M. Milligan, and B. Kirby. (2011). Operating Reserves and Variable Generation: A Comprehensive Review of Current Strategies, Studies, and Fundamental Research on the Impact That Increased Penetration of Variable Renewable Generation Has on Power System Operating Reserves. NREL/ TP-5500-51978. Golden, C0: National Renewable Energy Laboratory. Accessed December 2012: www.nrel.gov/docs/fy110sti/51978.pdf.

\section{More Information}

Erik Ela, 303-384-7089, erik.ela@nrel.gov

\footnotetext{
*A balancing authority is an entity responsible for maintaining balance between load and generation in a particular area at all times.
}

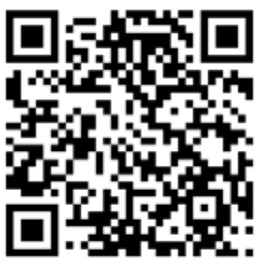

See our website at www.nrel.gov/electricity/transmission/.

Cover photos (from top): SunEdison, NREL/PIX 17423; Dennis Schroeder, NREL/PIX 21499; Dennis Schroeder, NREL/PIX 21605; Warren Gretz, NREL/PIX 10926
NREL is a national laboratory of the U.S. Department of Energy, Office of Energy Efficiency and Renewable Energy, operated by the Alliance for Sustainable Energy, LLC.

NREL/FS-5500-56596 • December 2012 